\title{
Nutritional status and lifestyle of liver cirrhotic patients in Kashmir
}

\begin{abstract}
Liver cirrhotic patients were investigated for their lifestyle, body mass index, biochemical and clinical signs of disease. The study included 500 liver cirrhotic patients who were visited and hospitalized in SKIMS and SMHS hospital Srinagar. The data was collected by using the self made questionnaire which was pretested on 10 patients. These ten patients were excluded from the study. Demographic data, level of education, biochemical values, clinical signs, weight, height and mid arm circumference was undertaken. Out of the 500 cirrhotic patients, $60 \%$ were from rural area and $40 \%$ were from urban area, $73.8 \%$ were males and $26.2 \%$ were females. It was observed that illiterates, laborers, married ones with nuclear type of family system from low economic status were being suffering from the liver cirrhosis. The disease is more seen in the age group of 46-60years. Low BMI and muscle wasting were present in almost all of the studied patients. Hyperbilirubinemia, low albumin and protein levels were observed in studied patients. Anemia, PEM, ascites, edema, muscle wasting were prevalent in vast majority of the patients.
\end{abstract}

Keywords: liver cirrhosis, body mass index, hyperbilirubinemia, anemia, stores essential, scar tissue, low albumin, hepatitis b virus, stadiometer, low albumin levels, non- stretchable tape, minitab, metric data, nausea, fatigue, vomiting
Volume 3 Issue I - 2017

\author{
Tahira Sidiq,' Nilofer khan, ${ }^{2}$ Feroz Ahmad \\ Wani, ${ }^{3}$ Abdul Majid Ganai, ${ }^{4}$ Bilal Ahmad ${ }^{5}$ \\ 'Research scholar Dietetics and clinical nutrition Institute of \\ Home Science University of Kashmir, India \\ ${ }^{2}$ Dean college Development council University of Kashmir, India \\ ${ }^{3}$ Professor and Head Department of Community Medicine \\ SKIMS Soura, India \\ ${ }^{4}$ Senior Resident, Department of Community Medicine SKIMS \\ Soura, India \\ ${ }^{5}$ Head, Division of Social Science, SKUAST, India
}

\begin{abstract}
Correspondence: Tahira Sidiq, Research scholar Dietetics and clinical nutrition Institute of Home Science University of Kashmir. 190006, Jammu and Kashmir, India, Email tahirasidiq86@gmail.com
\end{abstract}

Received: April 20, 2016 | Published: February 24, 2017
Abbreviations: SKIMS, sheri kashmir institute of medical science; SMHS, sheri maharaja hari singh hospital srinagar, BMI, body mass index; MAC, mid arm circumference; PEM, protein energy malnutrition; WHO, world health organization

\section{Introduction}

In today's life people are not foremost concerned with one's health and well being as they are busy with other priorities. They develop bad eating habits, making poor lifestyle choices and neglecting different aspects of health. In turn, these habits affect their body and overall health of the people. The liver is the second largest organ in human body. It is responsible for performing more functions than any other organ in the body, including metabolizing the food, filtering and detoxifying waste and toxic products, producing immune agents to control infection, and regenerating itself. ${ }^{1}$ It's another important function is to produce prothrombin and fibrinogen (blood-clotting factors) and heparin (that helps prevent blood from clotting within the circulatory system). The liver also synthesizes proteins, cholesterol and enzymes; produces and secretes bile; and stores essential micronutrients. The word "Cirrhosis" derives from the Greek word Kirrhos which means yellowish orange color of diseased liver of patient. It was Rene Laennec who gave the name "cirrhosis" in the year 1819..$^{2-4}$ As per WHO in 1978 cirrhosis is a disease which is characterized by fibrosis and the normal liver is converted to structurally abnormal nodules. ${ }^{5}$ When something affects and damages the liver, the cells of the liver gets killed and scar tissue is formed. The formation of scar tissue is called fibrosis and it slowly happens for several years and finally whole liver is involved and liver shrinks and hardens. This is called cirrhosis of the liver. Liver cirrhosis is characterized by poor life expectancy and is a leading cause of mortality and morbidity. Liver cirrhosis is the 12th leading cause of death in USA. ${ }^{6}$ Cirrhosis is the $3 \mathrm{rd}$ most common cause of death in people aged between 45 to $65 y$ years behind heart disease and cancer. Hepatitis B virus infection is most common cause of liver cirrhosis in India. It has been estimated that 1 million die annually from HBV related liver disease. ${ }^{7}$ Liver cirrhosis is one of the common health problems in Kashmir. This study has, therefore, investigated the nutritional status and lifestyle of liver cirrhotic patients in Kashmir.

\section{Materials and methods}

It was a cross sectional study conducted among 500 liver cirrhotic patients who visited or were admitted in Gastroenterology Department of SKIMS Soura and SMHS hospital Srinagar. The tool used in the present study was essentially a questionnaire. This was pre-tested on 10 liver cirrhotic respondents in order to ensure the validity and feasibility of questionnaire before administering it on the entire sample. The patients were explained about the purpose of the study, and on obtaining their consent; data were collected from the participating patients. Anthropometric measurements were measured, such as weight, height and mid arm circumference. Weight was measured using a digital weighing scale, height with a wall- mounted stadiometer and mid arm circumference with a non- stretchable tape. The body mass index was calculated using the formula proposed by quetelet $^{8} \mathrm{BMI}=$ weight $(\mathrm{kg}) /$ height $(\text { meter })^{2}$. Biochemical information was obtained from medical records of concerned respondents.

\section{Statistical analysis}

All data were statistically analyzed through statistical package for social science (SPSS) software version 20.00, Microsoft excel and Minitab. Metric data was described as mean $\pm \mathrm{SD}$. It's inter group comparisons were done by student's t- test and Man Whitney U test. Non parametric data was expressed and described as percentages. The intergroup comparison for such data was done by Chi-square analysis, Man Whitney U test was used for two-group comparisons 
in nonparametric data. Mean, SD, median and Z-test were used for anthropometric, laboratory and nutritive variables. Significance was evaluated as follows:

P-value: $>0.05$ (no-significant).

P-value: $<0.05$ (significant).

P-value: $<0.01$ (highly significant).

\section{Results}

The total studied respondents were 500 out of which 300 were from rural area and 200 were from urban area. It was observed that out of 300 rural respondents $222(44.4 \%)$ were males and $78(15.6 \%)$ were females (Table 1). Further, it was observed that out of 200 urban respondents $147(29.4 \%)$ were males and 53(10.6\%) were females.

Table I Distribution of Studied Respondents

\begin{tabular}{lllllll}
\hline \multirow{2}{*}{ Gender } & \multicolumn{2}{c}{ Rural $(\mathbf{n = 3 0 0})$} & \multicolumn{2}{c}{ Urban $(\mathbf{n = 2 0 0 )}$} & \multicolumn{2}{c}{ Total(n=500) } \\
\cline { 2 - 7 } & $\mathbf{N}$ & $\%$ & $\mathbf{N}$ & $\%$ & $\mathbf{N}$ & $\%$ \\
\hline Male & 222 & 44.4 & 147 & 29.4 & 369 & 73.8 \\
Female & 78 & 15.6 & 53 & 10.6 & 131 & 26.2 \\
Total & 300 & 60 & 200 & 40 & 500 & 100 \\
\hline
\end{tabular}

Table 2 Socioeconomic status of liver cirrhotic patients $(n=500)$

\begin{tabular}{|c|c|c|c|c|c|}
\hline \multirow{2}{*}{ Characteristics } & \multirow{2}{*}{ Residence } & \multicolumn{2}{|l|}{ Gender } & \multirow{2}{*}{$\mathbf{X}^{2}$} & \multirow{2}{*}{ P-value } \\
\hline & & $M(\%)$ & $F(\%)$ & & \\
\hline \multicolumn{6}{|l|}{ Marital status } \\
\hline \multirow{3}{*}{ Unmarried } & Urban & I $46(73.00)$ & $5 \mathrm{I}(25.50)$ & 0.03 & $>0.05$ \\
\hline & Rural & $6(2.00)$ & I $(0.33)$ & & \\
\hline & Urban & I $(0.50)$ & 0 & 0.163 & $>0.05$ \\
\hline \multirow{2}{*}{ Widow } & Rural & I $(0.33)$ & I $(0.33)$ & & \\
\hline & Urban & 0 & $2(3.77)$ & 1.33 & $>0.05$ \\
\hline \multicolumn{6}{|c|}{ Educational status } \\
\hline \multirow{3}{*}{ Primary } & Urban & $84(42.00)$ & $32(16.00)$ & 0.169 & $>0.05$ \\
\hline & Rural & $81(27.00)$ & $20(6.66)$ & & \\
\hline & Urban & $49(24.50)$ & $16(8.00)$ & 0.54 & $>0.05$ \\
\hline \multirow{2}{*}{ Secondary } & Rural & $9(3.00)$ & $2(0.66)$ & & \\
\hline & Urban & $14(7.00)$ & $5(2.50)$ & 0.258 & $>0.05$ \\
\hline \multicolumn{6}{|l|}{ Occupation } \\
\hline & Urban & $15(7.50)$ & I $(0.50)$ & 0.842 & $>0.05$ \\
\hline \multirow[t]{2}{*}{ Unemployed } & Rural & $10(3.33)$ & 0 & & \\
\hline & Urban & $5(2.50)$ & 0 & NA* & NA* \\
\hline \multirow[t]{2}{*}{ Laborer } & Rural & $199(66.33)$ & $4(1.33)$ & & \\
\hline & Urban & $127(63.50)$ & - & 2.533 & $>0.05$ \\
\hline \multirow[t]{2}{*}{ Retired } & Rural & - & - - & & - \\
\hline & Urban & - & - - & & \\
\hline \multirow[t]{2}{*}{ House wife } & Rural & $-74(24.66)$ & & & - \\
\hline & Urban & $-52(26.00)$ & & & \\
\hline \multicolumn{6}{|l|}{ Type of family } \\
\hline \multirow{3}{*}{ Joint } & Urban & $140(70.00)$ & $51(25.50)$ & 0.01 & $>0.05$ \\
\hline & Rural & $20(6.66)$ & $6(2.00)$ & & \\
\hline & Urban & $7(3.50)$ & $2(1.00)$ & 0.003 & $>0.05$ \\
\hline
\end{tabular}

Socioeconomic status of the liver cirrhotic patients is presented in (Table 2). It was observed that $96.93 \%(71.6 \%$ males \& $25.33 \%$ females) rural patients were married and in urban area $98.5 \%(73 \%$ males \& $25.5 \%$ females) studied respondents were married. Most of the patients investigated were illiterate $62.66 \%$ rural and $58 \%$ urban respondents. Regarding occupation of the studied respondents, in rural area majority of the males were laborers $(66.33 \%), 4.33 \%$ males were employed, $3.33 \%$ males were unemployed and $24.66 \%$ females were housewives. Further, it was observed that in urban area $63.5 \%$ males were laborers, $7.5 \%$ males were employed, $2.5 \%$ males were unemployed and $26 \%$ females were housewives. $91.33 \%$ rural \& $95.5 \%$ urban had nuclear type family and only $8.66 \%$ rural respondents and $34.5 \%$ urban patients had joint type family system. It was observed that majority $95.33 \%$ of rural studied respondents $(73 \%$ males \& $22.33 \%$ females) and $94.5 \%$ urban studied respondents $(72 \%$ males \& $22.5 \%$ females) belonged to lower socioeconomic class whose monthly income is Rs $<5000$. Statistically it was observed that there is a no-significant difference between socio demographic characteristics of studied liver cirrhotic respondents $(\mathrm{P}>0.05)$.

Figure 1 shows the age wise distribution of respondents. It was found that the disease is more prevalent in the age group of 46-60years (30.8\% were males and $13.4 \%$ were females) followed by the age group of $30-45$ years $(28.8 \%$ were males $\& 9.8 \%$ were females). 
Table Continued....

\begin{tabular}{|c|c|c|c|c|c|}
\hline \multirow{2}{*}{ Characteristics } & \multirow{2}{*}{ Residence } & \multicolumn{2}{|l|}{ Gender } & \multirow{2}{*}{$\mathbf{X}^{2}$} & \multirow{2}{*}{ P-value } \\
\hline & & $M(\%)$ & $F(\%)$ & & \\
\hline \multicolumn{6}{|l|}{ Economic status } \\
\hline (lower class) & Urban & I $44(72.00)$ & $45(22.50)$ & 0.009 & $>0.05$ \\
\hline $5000-10000$ & Rural & $2(0.66)$ & II (3.66) & & \\
\hline (Middle class) & Urban & $3(1.50)$ & $8(4.00)$ & 0.511 & $>0.05$ \\
\hline$>10000$ & Rural & I (0.33) & - & & - \\
\hline (Upper class) & Urban & - & & & \\
\hline
\end{tabular}

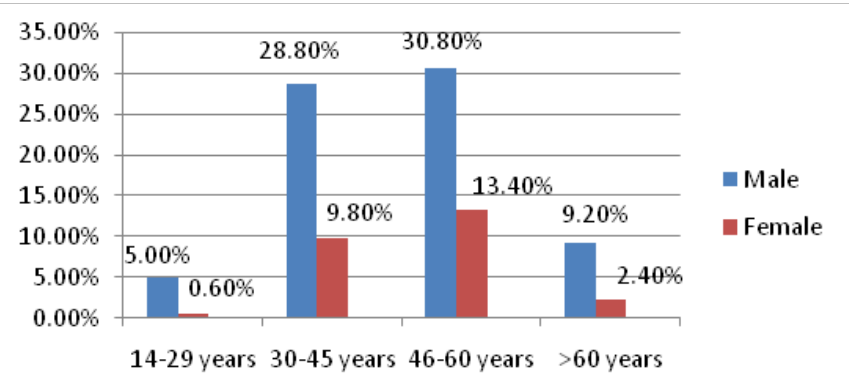

Figure I Distribution of patients as per age group.

Table 3 shows the average BMI and MAC values of the liver cirrhotic patients. The mean BMI of the rural male and female patients was (19.132 $\pm 2.117 \& 18.586 \pm 2.418)$ and in urban male and female patients it was $(18.96 \pm 2.214 \& 18.733 \pm 2.236)$. Mid arm circumference value of rural male and female patients was
$(19.316 \pm 2.839 \& 18.827 \pm 2.788)$ and in urban male and female patients it was $18.680 \pm 3.056 \& 18.253 \pm 3.170$ respectively. Statistically it was observed that there is highly significant difference between weight of male and female respondents of both areas and height of urban male and female respondents $(\mathrm{P}<0.01)$.

Biochemical analysis showed that mean hemoglobin value of rural male and female respondents is $(7.0912 \pm 1.4507 \& 7.242 \pm 1.419)$ and in case of urban male and female respondents $(7.099 \pm 1.566$ \& $7.379 \pm 1.839$ ) (Table 4) indicating they were anemic. Mean protein values of rural and urban patients were $(3.573 \pm 1.712 \& 4.271 \pm 1.940)$ and $(3.433 \pm 1.705 \& 3.934 \pm 1.719)$ respectively. Mean $\pm S D$ of bilirubin in rural patients is $(15.037 \pm 12.196 \& 18.08 \pm 16.24)$ and in urban patients is $(17.44 \pm 13.99 \& 10.72 \pm 9.36)$. Mean $\pm \mathrm{SD}$ of albumin in rural patients is $(1.5623 \pm 1.0001 \& 1.609 \pm 0.919)$ and in urban patients $(1.5036 \pm 1.152 \& 1.857 \pm 1.056)$ and Mean \pm SD of Creatinine in rural patients is $(7.0912 \pm 1.4507 \& 5.32 \pm 12.14$ and in urban patients is $(4.769 \pm 8.168 \& 5.46 \pm 8.61)$ respectively.

Table 3 Nutritional indices (BMI, MAC) of liver cirrhotic patients

\begin{tabular}{|c|c|c|c|c|c|}
\hline Variables & Residence & Gender & Mean \pm Sd & $Z$ value & P-value \\
\hline & Rural & $\begin{array}{l}\text { Male } \\
\text { Female }\end{array}$ & $\begin{array}{l}57.662 \pm 3.729 \\
20.397 \pm 6.362\end{array}$ & 9.526708 & $<0.01$ \\
\hline Weight(kg) & Urban & $\begin{array}{l}\text { Male } \\
\text { Female }\end{array}$ & $\begin{array}{l}56.942 \pm 3.184 \\
50.491 \pm 5.553\end{array}$ & 7.996729 & $<0.01$ \\
\hline & Rural & $\begin{array}{l}\text { Male } \\
\text { Female }\end{array}$ & $\begin{array}{l}1.5192 \pm 0.0626 \\
1.545 \pm 1.601\end{array}$ & -0.14228 & $>0.05$ \\
\hline Height(m) & Urban & $\begin{array}{l}\text { Male } \\
\text { Female }\end{array}$ & $\begin{array}{l}1.5235 \pm 0.0625 \\
1.5589 \pm 0.0150\end{array}$ & -6.37673 & $<0.01$ \\
\hline BMI & Urban & $\begin{array}{l}\text { Male } \\
\text { Female } \\
\text { Male } \\
\text { Female }\end{array}$ & $\begin{array}{l}19.132 \pm 2.117 \\
18.586 \pm 2.418 \\
18.96 \pm 2.214 \\
18.733 \pm 2.236\end{array}$ & I.770I & $>0.01$ \\
\hline $\operatorname{MAC}(\mathrm{cm})$ & Urban & $\begin{array}{l}\text { Male } \\
\text { Female } \\
\text { Male } \\
\text { Female }\end{array}$ & $\begin{array}{l}19.316 \pm 2.839 \\
18.827 \pm 2.788 \\
18.680 \pm 3.056 \\
18.253 \pm 3.170\end{array}$ & I.326187 & $>0.01$ \\
\hline
\end{tabular}


Table 4 Biochemical values of liver cirrhotic patients

\begin{tabular}{|c|c|c|c|c|c|}
\hline Values & Residence & Gender & Mean \pm Sd & $\mathbf{Z}$ value & P-value \\
\hline \multirow{4}{*}{ Hemoglobing/dl } & \multirow{2}{*}{ Rural } & Male & $7.0912 \pm 1.4507$ & -0.80269 & $>0.05$ \\
\hline & & Female & $7.242 \pm 1.419$ & & \\
\hline & \multirow{2}{*}{ Urban } & Male & $7.099 \pm 1.566$ & -0.98692 & $>0.05$ \\
\hline & & Female & $7.379 \pm 1.839$ & & \\
\hline \multirow{4}{*}{ Total Protein g/dl } & \multirow{2}{*}{ Rural } & Male & $3.573 \pm 1.712$ & -2.81567 & \\
\hline & & Female & $4.271 \pm 1.940$ & & $<0.01$ \\
\hline & \multirow{2}{*}{ Urban } & Male & $3.433 \pm 1.705$ & -1.82297 & $>0.05$ \\
\hline & & Female & $3.934 \pm 1.719$ & & \\
\hline \multirow{4}{*}{ Bilirubin mg/dl } & \multirow{2}{*}{ Rural } & Male & $15.037 \pm 12.196$ & -1.51184 & $>0.05$ \\
\hline & & Female & $18.08 \pm 16.24$ & & \\
\hline & \multirow{2}{*}{ Urban } & Male & $17.44 \pm 13.99$ & 3.889894 & $<0.01$ \\
\hline & & Female & $10.72 \pm 9.36$ & & \\
\hline \multirow{4}{*}{ Albumin $\mathrm{g} / \mathrm{dl}$} & \multirow{2}{*}{ Rural } & Male & $1.5623 \pm 1.0001$ & -0.37714 & \\
\hline & & Female & $1.609 \pm 0.919$ & & $>0.05$ \\
\hline & \multirow{2}{*}{ Urban } & Male & $1.5036 \pm 1.1523$ & -2.03788 & $<0.01$ \\
\hline & & Female & $1.857 \pm 1.056$ & & \\
\hline \multirow{4}{*}{ Creatinine mg/dl } & \multirow{2}{*}{ Rural } & Male & $7.0912 \pm 1.4507$ & 1.285315 & \\
\hline & & Female & $5.32 \pm 12.14$ & & $>0.05$ \\
\hline & \multirow{2}{*}{ Urban } & Male & $4.769 \pm 8.168$ & -0.50768 & $>0.05$ \\
\hline & & Female & $5.46 \pm 8.61$ & & \\
\hline
\end{tabular}

Careful perusal of the Figure 2 shows that all the studied respondents, both male and female had presence of all signs and symptoms of liver cirrhosis except ascites which was present only in $20 \%$ male respondents and $10 \%$ female respondents.

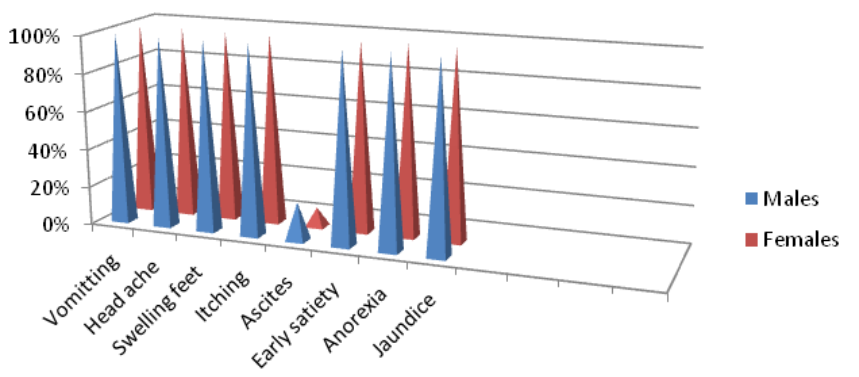

Figure 2 Clinical signs in liver cirrhotic patients.

\section{Discussion}

Liver cirrhosis is one of the common health problems in Kashmir. Infections and nutritional deficiency diseases are the "diseases of poverty." Poverty predisposes to malnutrition, the major public health problem in Kashmir valley. Likely malnutrition is frequent and common in liver cirrhosis. In the present study, most of the cirrhotic patients $(73.8 \%)$ males were more affected than females $(26.2 \%)$ with liver cirrhosis in both areas. It was observed that the $44.2 \%$ of the study respondents belonged to the age group of 46- 60 years, $38.6 \%$ of the study respondents belonged to $30-45$ years, $11.60 \%$ to $>60$ years and $5.60 \%$ of the study respondents belonged to the age group of 14-29years. The results of the present study were similar to the studies conducted by Singh et al. ${ }^{9}$ Teiusanu et al. ${ }^{10}$ Ullah, ${ }^{11}$ Chalasani, ${ }^{12}$ Arguedas ${ }^{13}$ and Nevens. ${ }^{9-14}$ In the present study most of the patients were married, illiterate, laborers with nuclear type of family system and had low socio economic group are more vulnerable to this disease. These results were somewhat consistent with the reports of Idris SM et al. ${ }^{15}$ Khan $\mathrm{R}$ et al, ${ }^{16}$ Corrao $\mathrm{G}^{17}$ and Ahsan T. ${ }^{15-18}$ The present study observed that $47.8 \%$ males and $26.2 \%$ females had BMI $<18.5 \mathrm{Kg} /$ $\mathrm{m}^{2}$ and $22.6 \%$ males and $9.8 \%$ females had normal BMI value 18.5 $22.9 \mathrm{Kg} / \mathrm{m}^{2}$. In a study conducted by Tail MS et al. ${ }^{19}$ on 36 Malaysia cirrhotic patients which revealed that anthropometric values in males was (BMI $18.1 \pm 1.6$ vs $26.3 \pm 3.5 \mathrm{Kg} / \mathrm{m}^{2}$ ) and females (BMI $19.4 \pm 2.7$ vs $28.9 \pm 4.3 \mathrm{Kg} / \mathrm{m}^{2}$ ). Roongpisuthipong $\mathrm{C}$ et al. ${ }^{20}$ observed the same observation in their study that out of 60 studied patients $17.8 \%$ had body mass index below $18.5 \mathrm{Kg} / \mathrm{m}^{2}$. The present study also observed that muscle wasting was present in studied respondents. A study conducted by Teiusanu A et al. ${ }^{21}$ on 176 patients revealing that mid arm circumference was decreased according to the child score and significant correlation was found between MAC and severity of the disease. ${ }^{21}$ The present study identified a high prevalence of anemia, hyperbilirubinemia, low albumin levels, low serum protein levels, and high creatinine levels. These values are deviated from the normal 
values especially in the age group of $46-60$ years. ${ }^{22,23}$ These signs interfere with the intake of dietary intake which leads to malnutrition in these patients. A study conducted by Carvalho et al. (2006) on 300 liver cirrhotic patients revealed that $55 \%$ of the studied respondents had insufficient food intake due to presence of discomforts like nausea, fatigue, vomiting and swelling. ${ }^{24}$ Our results also related with the findings of Ahsan $\mathrm{T}^{18}$ revealed that majority of the studied respondents were suffering from ascites, edema, nausea, vomiting and muscle wasting. ${ }^{18}$

\section{Conclusion}

This disease is more seen in males from rural areas having nuclear type of family system and belonged to low socioeconomic group. Malnutrition is highly prevalent among Kashmir individuals with liver cirrhosis. Patients with cirrhosis had relatively low BMI, mid arm circumference, hemoglobin, protein and albumin levels. There is significant correlation between these parameters and severity of the disease.

\section{Acknowledgements}

None.

\section{Conflict of interest}

Author declares that there is no conflict of interest.

\section{References}

1. NIDDK. Cirrhosis of the Liver. MD National Institute of Diabetes and Digestive and Kidney Diseases/National Institutes of Health. NIH, Bethesda, USA; 2000.

2. Roguin A. Rene Theophile Hyacinthe Laennec the Man behind the Stethoscope. Clin Med Res. 2006;4(3):230-235.

3. Arey LB, Burrows W, Greenhill JP, et al. Dorland's illustrated medical dictionary. 23rd ed. USA: Press of WB Saunders Company; 1962. 286p.

4. Duffin JM. Why does cirrhosis belong to Laennec? CMAJ. 1987;137(5):393-396.

5. Anthony PP, Ishak KG, Nayak NC, et al. The morphology of cirrhosis. Recommendations on definition, nomenclature, and classification by a working group sponsored by the World Health Organization. J Clin Pathol. 1978;31(5):395-414.

6. Rockville. Action plan for liver disease research. Department of Health and Human Services, National Institutes of Health. NIH. 2004.

7. Khuroo MS. Liver disease in Kashmir: despair \& hope. Kashmir, India; 2012.

8. University of Minnesotta Morris.

9. Singh N, Choudhary JK, Srivastava N, et al. Nutritional And Clinical Profile of Patients in Different Stages of Alcoholic and Virus Related Liver Disease: An Indian Perspective Web med Central plus. Gastroenterology. 2013;39(1):WMCPLS00239.
10. Teiusanu A, Mirela Ionescu, Gologan S, et al. Dietary therapy impact for cirrhotic patients with hepatic encephalopathy. Jurnalul de chirurgie (Iasi). 2012;8(4):373-378.

11. Ullah F, Khan S, Afridi AK, et al. Frequency of different causes of cirrhosis liver in local population of Pakistan. Gomal J Med Sci. 2012;10:178-181.

12. Chalasani N, Kahi C, Francois F, et al. Improved patient survival after acute variceal bleeding: a multicenter, cohort study. Am J Gastroenterol. 2003;98(3):653-659.

13. Arguedas MR, McGuire BM, Fallon MB, et al. The use of screening and preventive therapies for gastro-esophageal varices in patients referred for evaluation of orthotopic liver transplantation. Am J Gastroenterol. 2001;96(3):833-7.

14. Nevens F, Broeckaert L, Rutgeerts P, et al. The long term morbidity and mortality rate in a cohort of patients with liver cirrhosis and oesophageal varices. Hepatogastroenterology. 1995;42(6):979-984.

15. Idris SM, Ali E AL. Assessment of Dietary Management of Patients with Cirrhosis. IJSR. 2013;2(6):47-53.

16. Khan R, Ahmed A, Ismail FW, et al. Perception and Knowledge About Dietary Intake in Patients with Liver Cirrhosis and its Relationship with the Level of Education. J Coll Physicians Surg Pak. 2012;22(7):435-439.

17. Corrao G, Antonella Zambon, Vincenzo Bagnardi, et al. Nutrient intakes, nutritional pattern in liver cirrhosis. Eur $J$ Epidemiol. 2004;19(9):861-869.

18. Ahsan T, Ahsan M, Kamal M, et al. Lifestyle, nutritional status and seroclinical profile of liver cirrhotic patients. Bangladesh medical journal. 2007;36(2):44-47.

19. Tai1 MS, Goh KL, Mohd-Taib SW, et al. Anthropometric, biochemical and clinical assessment of malnutrition in Malaysian patients with advanced cirrhosis. Nutr J. 2010;9:27.

20. Roongpisuthipong C, Sobhonslidsuk A, Nantiruj K, et al. Nutritional assessment in various stages of liver cirrhosis. Nutrition. 2001;17(9):761-765.

21. Teiusanu A, Andrei M, Arbanas T, et al. Nutritional Status in Cirrhotic Patients. Maedica (Buchar). 2012;7(4):284-289.

22. Nishiguchi MSS, Masaki Saito, Yoshitaka Fukuzawa, et al. Nutritional status and quality of life in current patients with liver cirrhosis as assessed in 2007-2011. Hepatol Res. 2013;43(2):106-112.

23. Salma H, Badruddin, Wasim Jafri SM, et al. Dietary practices and beliefs of patients with chronic liver disease. J Pak Med Assoc. 1999;49(9):216-20.

24. Campillo B, Richardet JP, Scherman E, et al. Evaluation of nutritional practice in hospitalized cirrhotic patients: results of a prospective study. Nutrition. 2003;19(6):515-521. 